\title{
IDEOLOGI AKTOR DAN PERSEPSI MASYARAKA TERHADAP DAMPAK PERTAMBANGAN PASIR DI PEDESAAN GUNUNG GALUNGGUNG
}

\author{
Actor Ideology and Public Perception of Sand Mining Impacts on Rural Galunggung Mountain
}

Faris Rahmadian*) dan Arya Hadi Dharmawan

Departemen Sains Komunikasi dan Pengembangan Masyarakat, Fakultas Ekologi Manusia, IPB

*)Email : farisrahmadian@gmail.com

\begin{abstract}
After the eruption, the region of Galunggung is one of area that become contestation arena between the interests of the government, public and private. The abundant of sand mining object, make large scale mining industry came in and implicates essentially on the lives of local communities who are not only close to the mining area, but also are away from the mining area. Moreover, it is known that the public ideology is emphasizes to welfare and populism, inversely proportional to the private and government ideology that emphasizes to profit and developmentalism. Negative and positive impacts of mining activity started significantly perceived by the public, such as degradation of water quality, the level of income, or conflict that represents the community response to the presence of sand mining company that has been almost thirty years to dredge this area.
\end{abstract}

Keywords: Actor analysis, impact assessment, public perception, natural resources utilization, sand mining

\begin{abstract}
ABSTRAK
Pasca erupsi, kawasan Gunung Galunggung merupakan salah satu kawasan yang menjadi arena besar pertarungan kepentingan antara pemerintah, masyarakat dan swasta. Objek pasir yang berlimpah menjadikan pertambangan skala besar hadir dan berimplikasi secara esensial terhadap kehidupan masyarakat lokal yang tidak hanya berada dekat dengan kawasan pertambangan, namun juga berada jauh dengan lokasi pertambangan. Terlebih diketahui bahwa ideologi masyarakat yang menekankan pada kesejahteraan dan populisme, berbanding terbalik dengan ideologi swasta dan pemerintah yang menekankan pada profit dan pembangunan. Dampak negatif dan positif aktivitas pertambangan mulai secara nyata dirasakan oleh masyarakat, diantaranya seperti degradasi kualitas air, tingkat pendapatan atau konflik yang secara krusial merepresentasikan respons masyarakat terhadap keberadaan perusahaan pertambangan pasir yang telah hampir tiga puluh tahun mengeruk kawasan ini.
\end{abstract}

Kata kunci: Analisis aktor, analisis dampak, pemanfaatan sumber daya alam, persepsi masyarakat, pertambangan pasir

\section{PENDAHULUAN}

Indonesia telah merumuskan bahwa pemanfaatan sumber daya alam adalah untuk memajukan kesejahteraan bersama, seperti yang termuat dalam filosofi dasar negara yaitu Undang-Undang Dasar 1945. Untuk mewujudkan cita-cita tersebut, perlu adanya pengelolaan sumber daya alam yang serasi dan seimbang untuk menunjang pembangunan yang berkesinambungan, yang memperhitungkan kebutuhan generasi sekarang dan mendatang. Sebagai lembaga formal, aparatur pemerintahan memiliki kewenangan dalam mengatur dan mengelola sumber daya alam di daerahnya, namun hak otonom pemerintah kerap menjadi dalih pemerintah daerah atas kewenangan secara mutlak dalam segala aspek yang terdapat di daerahnya (Tarmansyah 2011).

Kementrian Energi dan Sumber Daya Mineral (ESDM) pada tahun 2012 menyebutkan, pada sektor pertambangan setidaknya terdapat 5.940 izin usaha pertambangan (IUP) yang dinyatakan masih bermasalah, baik dari segi perizinan, kepemilikan lahan, dan lain sebagainya (Wihardandi 2012). Terlebih pada era ini, isu pertambangan seolah semakin kompleks dan dipenuhi polemik, walaupun legalitas pertambangan belum diperoleh, banyak perusahaan tambang yang tetap melakukan aktivitas pertambangannya, dan lagi-lagi permasalahan seperti ini terjadi karena banyaknya oknumoknum baik swasta maupun pemerintah sendiri yang memiliki otoritas namun cenderung berorientasi profit tanpa mempertimbangkan aspek kepentingan dan hak-hak khalayak banyak. Padahal perlu untuk dipahami, bahwa urgensi sumber daya alam sama sekali bukan hanya berada pada tataran kepentingan ekonomi apalagi politik belaka. Bagi masyarakat khususnya masyarakat yang rentan atau miskin, sumber daya alam merupakan aspek krusial yang menyangkut hidup dan mati diri serta keluarganya. Seperti yang disebutkan oleh Dharmawan (2006), sumber daya alam adalah "last resort" atau tempat pengaduan terakhir bagi lapisan masyarakat miskin untuk mempertahankan kehidupannya (survival strategy), oleh karena itu sumber daya alam bukanlah sekedar 
permasalahan yang ada di permukaan, namun esensial dan seharusnya menjadi prioritas isu nasional yang memerlukan sinergi seluruh stakeholder terkait.

Berdasarkan pernyataan tersebut, masyarakat seolah "mengukuhkan" posisinya yang berada pada posisi inferior diantara para pemilik kepentingan, dan tidak memiliki kekuasaan serta hak atas sumber daya alam yang berada di lingkungannya sendiri. Kondisi yang dialami oleh masyarakat ini semakin diperparah ketika dampak-dampak yang ditimbulkan oleh pemanfaatan sumber daya alam tersebut ternyata juga menggangu dan merugikan pihak masyarakat. Kerusakan lingkungan yang ditimbulkan akibat aktivitas pemenafaatan sumber daya alam tentunya akan berdampak baik secara langsung maupun tidak langsung terhadap mata pencaharian mereka, kondisi lingkungan dan tentunya juga ekosistem secara keseluruhan di kawasan sekitarnya.

Gambaran-gambaran tersebut seolah direfleksikan secara nyata di kawasan Gunung Galunggung, Jawa Barat. Beberapa titik di kawasan Gunung Galunggung, khususnya di daerah Kecamatan Padakembang telah menjadi kawasan pengerukan pasir berbagai pihak, diantaranya oleh CV PG, CV AS dan CV FR. Walaupun kehadiran perusahaan seperti CV AS bukan yang pertama di kawasan ini, namun bagi masyarakat sekitar lokasi pertambangan, perusahaan tambang yang masih eksis pada saat ini yakni CV AS, merupakan salah satu perusahaan yang dianggap membawa perubahan kondisi lingkungan, sosial dan bahkan ekonomi masyarakat sekitar lokasi tambang menuju ke arah negatif secara nyata.

Kawasan Gunung Galunggung memang memiliki jumlah material pasir yang sangat berlimpah. Pasca erupsi pada tahun 1982 dan berakhir pada bulan Januari 1983, Gunung Galunggung seolah telah menjadi "ladang" pasir serta material bebatuan lainnya yang dihasilkan oleh letusan gunung. Walaupun tragedi tahun 1982 - 1983 dianggap sebagai bencana besar yang banyak menyebabkan berbagai kerugian baik moril maupun materil, dan sebagai salah satu bencana letusan gunung terburuk di Indonesia, namun di satu sisi bencana tersebut dianggap telah membawa manfaat yang banyak bagi masyarakat, baik yang berada sekitar kawasan Gunung Galunggung maupun yang berasal dari luar kawasan. Manfaat yang dimaksud adalah hadirnya sektor pertambangan di kawasan Gunung Galunggung, pasir yang berlimpah dan awalnya hanya dimanfaatkan masyarakat untuk berbagai keperluan, mulai menarik masuk berbagai investasi skala industri yang juga ingin turut serta mengeruk kekayaan tambang pasir yang berlimpah di kawasan Gunung Galunggung. Namun pasca runtuhnya era orde baru, pertambangan pasir yang pada awalnya dianggap masyarakat sebagai berkah, justru lambat laun membuat masyarakat malah "terganggu".

Pertambangan pada era ini semakin mengarah pada permasalahan komperhensif yang tidak jarang menggiring pada ancaman krisis ekologi yang serius. Terlebih jika ditinjau dari sudut pandang ekonomi, tidak jarang isu pertambangan menjadi dua sisi yang saling bertolak, yang menguntungkan bagi daerah atau sebagian kelompok kapitalis dan berkepentingan, namun merugikan dan bahkan mengancam eksistensi masyarakat yang berada di sekitar kawasan aktivitas tambang itu sendiri.
Padahal dengan penghasilan dan keuntungan dari sektor pertambangan yang besar baik pada daerah maupun negara, sudah seharusnya kesejahteraan masyarakat sekitar kawasan tambang menjadi prioritas dan diperhatikan secara khusus dalam mencapai kesejahteraannya. Ancaman dampak pertambangan pasir di kawasan kaki Gunung Galunggung pada saat ini secara nyata telah mengarah pada ancaman krisis ekologi dan menjadi isu dan polemik yang kompleks, maka berdasarkan uraian tersebut, perlu dilakukan penelitian untuk mengetahui bagaimana ideologi aktor dan persepsi masyarakat terhadap dampak pertambangan pasir di kawasan pedesaan Gunung Galunggung.

\section{Rumusan Masalah}

Lingkungan dan sumber daya alamnya pada era ini merupakan isu masyarakat global yang berkaitan dengan jaringan interaksi politik yang paling kompleks. Lingkungan beserta sumber daya alamnya dianggap sebagai objek yang selalu berkaitan dengan pola-pola interaksi dan variasi yang paling rumit, dan sekaligus dengan pelibatan aktor yang paling majemuk (Lay 2007). Demikian halnya dengan kasus pemanfaatan sumber daya alam di kawasan Gunung Galunggung. Aktor-aktor yang terlibat di dalamnya sangatlah beragam, terlebih mengingat aktivitas pertambangan pasir yang dilakukan oleh perusahaan didalamnya bukan lagi dalam ruang lingkup pertambangan skala kecil, namun termasuk pada skala besar, sehingga memerlukan berbagai izin serta proses yang panjang baik dengan pihak pemerintah dan juga masyarakat. Perbedaan kepentingan antara masyarakat, pemerintah dan swasta secara jelas kerap terlihat, sumber daya alam yang seharusnya juga menjadi hak masyarakat seolah direbut secara paksa oleh pihak yang tiba-tiba datang dengan kekuatan industrinya dan secara perlahan mengancam eksistensi mereka.

Pemanfaatan sumber daya alam yang tendensius dan tidak mengindahkan aspek-aspek ekologis jelas akan berdampak buruk terhadap kondisi ekosistem dan lingkungan sekitarnya. Terlebih aktivitas pertambangan pasir yang dilakukan di kawasan Gunung Galunggung telah dilakukan sejak lama. Sehingga dampak yang ditimbulkan tidak hanya sebatas pada aspek ekologis, namun lebih esensial dan bahkan hingga menyentuh aspek sosial dan ekonomi masyarakat. Bahkan, dampak tersebut tidak hanya dirasakan oleh masyarakat yang berada dekat dengan lokasi tambang, namun juga yang berada jauh dengan lokasi tambang. Oleh karena itu, berdasarkan uraian tersebut, maka penelitian ini akan membahas dua rumusan masalah sebagai berikut:

1. Bagaimana ideologi dan peran para aktor yang terlibat dalam aktivitas pertambangan pasir di kawasan kaki Gunung Galunggung?

2. Sejauh mana persepsi masyarakat terhadap dampak negatif ekologi, sosial dan ekonomi yang ditimbulkan oleh aktivitas pertambangan pasir di kawasan kaki Gunung Galunggung?

\section{Tujuan Penelitian}

Berdasarkan rumusan masalah penelitian, maka penelitian ini secara khusus bertujuan untuk: 
1. Mengetahui ideologi dan peran para aktor yang terlibat dalam aktivitas pertambangan pasir di kawasan kaki Gunung Galunggung.

2. Mengetahui sejauh mana persepsi masyarakat terhadap dampak negatif yang ditimbulkan oleh aktivitas pertambangan pasir, baik pada aspek ekologi, sosial, dan ekonomi.

\section{PENDEKATAN TEORITIS}

\section{Tinjauan Pustaka}

\section{Urgensi Ekologi}

Manusia akan selalu berinteraksi dan terintegrasi dengan suatu sistem lingkungan hidup. Namun terkadang, manusia melupakan bahwa interaksi dan hubungan manusia dengan lingkungan atau sumber daya alamnya terjalin hubungan yang resiprokal. Itulah yang menjadi basis dalam konsep ekologi, yang berfokus pada hubungan timbal balik antara manusia dengan lingkungannya. Dalam konsep ekologi, ekosistem dimaknai sebagai sistem-sistem dalam lingkungan yang terdiri atas komponen-komponen (baik komponen biotik maupun abiotik) yang bekerja secara teratur sebagai suatu kesatuan.

Soemarwoto (1997) juga menjelaskan jika ekologi merupakan salah satu komponen dalam sistem pengelolaan lingkungan hidup yang harus ditinjau bersama dengan komponen lain untuk mendapatkan keputusan dan hasil yang seimbang antara elemen makhluk hidup dan lingkungan itu sendiri. Sehingga aspek ekologi merupakan salah satu aspek yang harus secara krusial diperhatikan, terlebih dalam kaitannya dengan konteks pemanfaatan sumber daya alam. Keraf (2010) juga secara tidak langsung menyatakan dalam berbagai permasalahan ekologi hingga ancaman krisis yang terjadi pada dewasa ini, tidaklah hanya disebabkan oleh faktor alam, namun juga faktor internal dari manusia sebagai pihak yang terus menerus berinteraksi dengan lingkungannya.

\section{Konsepsi Pertambangan}

Pertambangan adalah sebagian atau seluruh tahapan kegiatan dalam rangka penelitian, pengelolaan dan pengusahaan objek tambang yang rneliputi penyelidikan umum, eksplorasi, studi kelayakan, konstruksi, penambangan, pengolahan dan pemurnian, pengangkutan dan penjualan, serta kegiatan pascatambang (UU No. 4 Tahun 2009). Undang-undang Negara Indonesia juga telah secara jelas meengklasifikasikan jenis terkait izin usaha pertambangan menjadi tiga. Ketiga jenis izin tersebut meliputi izin untuk memanfaatkan bahan galian tambang yang bersifat ekstraktif seperti (1) Galian tambang golongan $\mathrm{A}$, seperti minyak bumi, batu bara gas alam dll (2) galian tambang golongan B, seperti bauksit, besi, emas, intan, dll (3) galian tambang golongan $\mathrm{C}$, seperti pasir, tanah uruk, dan batu kerikil (Ngadiran dalam Samad 2013).

Galian tambang golongan $\mathrm{C}$ termasuk di dalamnya objek tambang pasir, dianggap paling kurang memiliki nilai strategis dan dampak yang vital. Padahal banyak fakta dilapangan justru menunjukkan galian tambang golongan
C juga memiliki dampak yang krusial, seperti pencemaran air yang diakibatkan kontaminasi limbah hasil sisa dari kegiatan pertambangan, pencemaran atau polusi udara, dan sebagainya. Karena bagaimanapun juga, lingkungan merupakan suatu kesatuan ruang yang terdiri dari komponen fisik (abiotik) seperti air, tanah, batuan dan iklim serta komponen biotik seperti tumbuhan, hewan dan jasat renik yang tidak berdiri sendiri-sendiri, tetapi memiliki keterkaitan antara satu unsur dengan unsur lainnya, dan dapat terpengaruh jika terdapat aktivitas atau perubahan baik yang dilalaui melalui proses alamiah maupun perbuatan manusia (Indrawan dalam Suriansyah 2009).

\section{Persepsi}

Persepsi memiliki makna sebagai suatu proses kognitif yang dialami dan dimiliki oleh setiap orang dalam kaitannya dengan memahami informasi tentang lingkungannya, baik lewat penglihatan, pendengaran, penghayatan, perasaan, dan penciuman (Thoha 2004). Berdasarkan definisi tersebut, persepsi memiliki sudut pandang subjektif yang tentunya akan dapat berbeda pada setiap manusia, karena proses kognitif, penafsiran serta pemaknaan terhadap subjek atau objek tertentunya akan memiliki bentuk atau intensitas yang berbeda.

Banyak faktor yang pada dasarnya mempengaruhi persepsi dari individu itu sendiri, baik yang berasal dari faktor internal maupun eksternal, diantaranya seperti kondisi lingkungan, jenis pekerjaan, status sosial, karakteristik sosial dan ekonomi Erwiantono (2004).

\section{Kerangka Penelitian}

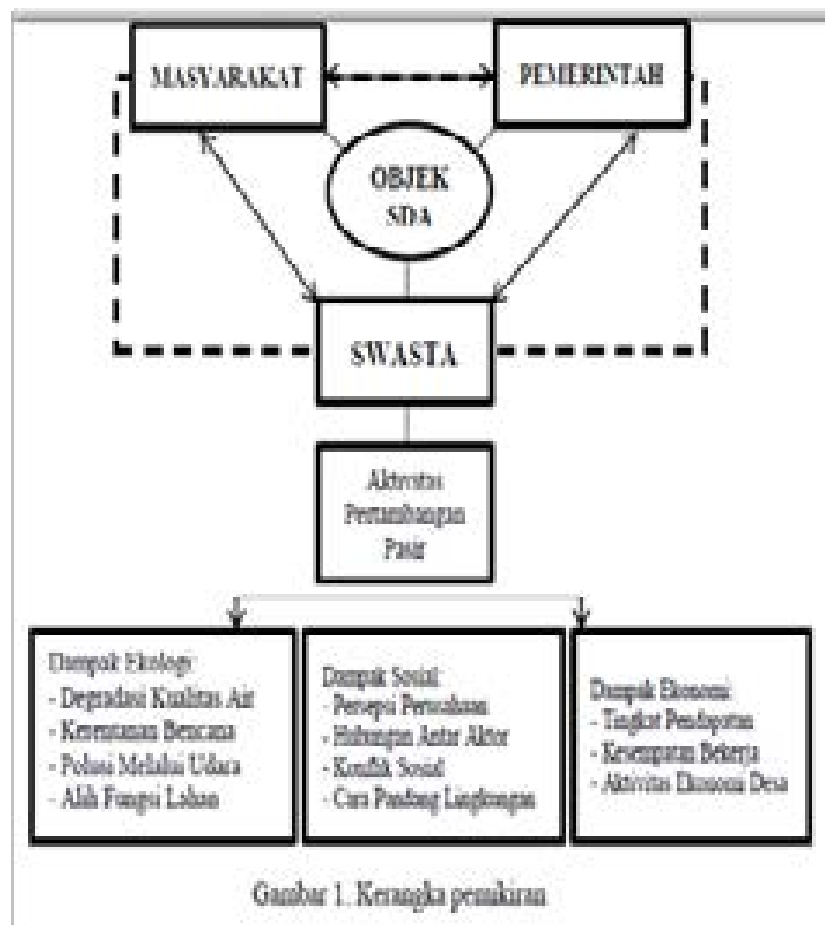

Pada dasarnya pemerintah, swasta dan masyarakat merupakan pihak yang saling berkaitan dalam rangka pemanfaatan sumber daya alam. Objek sumber daya alam yang dimanfaatkan dalam penelitian ini adalah sumber 
daya alam pertambangan dengan objek spesifik pasir Walaupun sebenarnya pasir tidak dimanfaatkan secara langsung oleh masyarakat, namun pasir yang tersedia dan terdapat di kawasan ini merupakan komponen vital yang juga turut menjaga keseimbangan ekosistem wilayah Gunung Galunggung.

Dengan kehadiran aktivitas pertambangan pasir pasir berskala besar, eksistensi kawasan dan degradasi lingkungan akan terus menggiring kawasan Gunung Galunggung pada ancaman krisis ekologi yang serius. Dampak-dampaknya pun meliputi berbagai aspek, diantaranya pada aspek ekologi, sosial dan ekonomi (Gambar 1). Masyarakat merupakan suatu kesatuan yang dinamis. Oleh karena itu, dalam relevansinya dengan aktivitas pertambangan skala industri yang dilakukan oleh pihak swasta, tidak jarang respons yang diterima oleh masyarakat sangatlah variatif, baik bersifat positif maupun negatif, baik yang berada pada tataran fisik, atau juga dapat jauh lebih dalam melalui perubahan-perubahan persepsi. Oleh karena itu penelitian ini juga mengarah pada analisis antar aktor dalam kaitannya dengan pemanfaatan sumber daya alam, proses politik dan kebijakan, hingga aktivitas pertambangan yang dilakukan oleh pihak swasta, serta dampak-dampak yang ditimbulkan termasuk persepsinya dari masyarakat baik pada aspek ekologi, sosial dan ekonomi.

\section{METODOLOGI}

Pendekatan penelitian yang dilakukan dalam penelitian ini adalah pendekatan kuantitatif yang didukung dengan pendekatan kualitatif. Penelitian dilakukan di dua lokasi, yakni desa yang berada dekat dengan aktivitas pertambangan pasir: (1) Desa Mekarjaya, Kecamatan Padakembang, Kabupaten Tasikmalaya, Provinsi Jawa Barat dan desa yang berada jauh dengan aktivitas pertambangan pasir: (2) Desa Rancapaku, Kecamatan Padakembang, Kabupaten Tasikmalaya, Provinsi Jawa Barat.

Penelitian ini dilakukan melalui pengumpulan data primer maupun data sekunder. Data primer merupakan data yang diperoleh langsung dari lapangan, baik melalui observasi, kuesioner, dan kegiatan wawancara mendalam (in-depth interview) yang dilakukan pada responden maupun pada informan. Untuk kuesioner, terdiri dari 55 pernyataan untuk pengukuran persepsi, dan akumulasi skor akan dibagi secara ordinal dalam tiga kategori sesuai dengan porsi masing-masing variabel yang ditanyakan. Sedangkan data sekunder merupakan data yang diperoleh baik berupa dokumen-dokumen dari pemerintah desa, masyarakat ataupun pihak lainnya yang berkaitan, serta literatur-literatur yang menunjang data ataupun deskripsi kondisi yang berkaitan dengan penelitian.

Penentuan responden dipilih dengan simple random sampling. Responden terdari dari 30 orang yang berasal dari Desa Mekarjaya, dan 30 orang yang berasal dari Desa Rancapaku. Sedangkan pemilihan terhadap informan, dilakukan secara sengaja (purposif) dan jumlahnya tidak ditentukan. Penetapan informan dalam wawancara ditentukan melalui metode snowball, yaitu berdasarkan informasi antar responden di lokasi penelitian. Orangorang yang dijadikan sebagai informan dalam penelitian ini beragam, baik yang berasal dari pemerintahan, masyarakat, baik tokoh masyarakat, masyarakat yang tinggal dekat lokasi pertambangan, masyarakat yang pernah bekerja di pertambangan, maupun masyarakat yang memiliki informasi terkait dengan kasus yang diteliti.

Penelitian ini mempunyai dua jenis data yang akan diolah dan dianalisis, yaitu data kuantitatif dan data kualitatif. Data kuantitatif diolah dengan menggunakan Microsoft Excel 2010. Pembuatan tabel tabulasi silang, tabel frekuensi, grafik, serta diagram diolah menggunakan aplikasi tersebut. Sedangkan untuk data kualitatif, data ini dianalisis melalui proses penafsiran dan penarikan kesimpulan dari hasil wawancara yang tertulis dalam catatan harian. Proses ini pada intinya bertujuan untuk menyimpulkan data yang lebih relevan dan objektif, namun terdapat juga data hasil wawancara yang secara utuh (dengan pengubahan seperlunya) yang langsung disajikan oleh penulis dalam kutipan wawancara.

\section{PROFIL MASYARAKAT DESA MEKARJAYA DAN DESA RANCAPAKU}

\section{Letak Geografis dan Keadaan Lingkungan}

Desa Mekarjaya dan Desa Rancapaku merupakan desa yang termasuk dalam wilayah Kecamatan Padakembang. Kedua desa ini berada tepat di kawasan kaki Gunung Galunggung, yang merupakan salah satu gunung berapi yang masih aktif yang ada di Jawa Barat. Di kawasan ini, terdapat varian flora dan fauna yang beragam, pasalnya sebagaian besar kawasannya adalah hutan montane, atau hutan yang berada pada dataran rendah dimana rimbunnya pepohonan besar hingga hewan-hewan seperti kera mendominasi kawasan hutan ini. Selain itu aliran sungai besar, seperti Sungai Ciwulan dan Sungai Cikunir juga mengalir deras dari puncak Gunung Galunggung yang sering juga dimanfaatkan oleh masyarakat untuk berbagai kegiatan mereka.

Namun, Gunung Galunggung merupakan Gunung berapi yang masih aktif. Hal ini tentunya juga berpengaruh besar khususnya terkait dengan kondisi ekosistem di dalamnya. Apalagi letusan gunung berapi merupakan salah satu bencana alam yang dapat berakibat fatal, dan dampaknya pun dapat bersifat permanen dan dapat dirasakan dalam jangka waktu yang lama. Terhitung setidaknya Gunung Galunggung telah memuntahkan lahar panasnya sebanyak empat kali, yakni pada tahun 1882, 1894, 1918, dan yang terakhir adalah 1982

Dari korban jiwa, hingga harta benda harus dikorbankan oleh masyarakat sebagai konsekuensi tinggal di kawasan gunung berapi aktif yang harus dirasakan baik oleh masyarakat Desa Mekarjaya maupun Desa Rancapaku. Terlebih mengingat kedua desa tersebut merupakan desa yang dilalui oleh jalur aliran lahar, sehingga implikasi yang diakibatkan oleh letusan cukup masif dirasakan masyarakat kedua desa.

\section{Struktur Sosial dan Ekonomi}

Secara spesifik baik Desa Mekarjaya maupun Desa Rancapaku, memiliki kondisi dan karakteristik sosial dan ekonomi yang kurang lebih sama. Pasalnya Desa Mekarjaya merupakan desa hasil pemekaran dari Desa Rancapaku yang dilakukan pada tahun 1978, dimana penduduknya bermata pencaharian beragam, mulai dari petani, peternak ikan, wiraswasta hingga buruh. Namun 
keadaan sosial dan ekonomi masyarakat juga secara nyata dipengaruhi oleh letusan Gunung Galunggung yang terjadi pada tahun 1982 - 1983, dimana erupsi tersebut menyebabkan timbunan pasir di sebagian besar desa, yang nantinya dimanfaatkan juga oleh masyarakat.

Struktur penghidupan yang beragam yang dimiliki kedua desa ini juga dapat digolongkan menjadi basis pertambangan dan juga non-pertambangan. Namun pada dasarnya basis pertambangan hanya dimiliki oleh masyarakat yang berasal dari Desa Mekarjaya, berbeda dengan masyarakat yang berasal dari Desa Rancapaku, dimana menurut keterangan pihak pemerintah sama sekali tidak ada warganya yang bekerja di sektor pertambangan sejak lama. Pola pekerjaan yang lebih bervariasi pada Desa Mekarjaya diantaranya ditunjukkan dengan hadirnya warga yang tidak hanya bekerja sebagai petani ataupun wiraswasta, namun juga terkadang masuk pada sektor pertambangan baik sebagai buruh tambang atau supir truk, sehingga pada akhirnya juga memunculkan kondisi ekonomi dan sosial yang lebih kompleks. Banyak pihak yang secara langsung maupun tidak langsung bergantung pada sektor pertambangan, baik pekerja atau buruh tambang itu sendiri ataupun pemilik warung makan yang dibuka di sekitar lokasi tambang. Namun walaupun demikian, dapat dikatakan juga bahwa sebagian besar masyarakat Desa Mekarjaya masih tetap menggantungkan penghidupannya pada sektor pertanian pada skala prioritas, hal ini karena pekerjaan pada sektor pertambangan bukanlah pekerjaan yang bersifat mengikat, namun hanya temporer dan bersifat kontrak berkala saja.

Kondisi masyarakat menggantungkan penghidupannya pada sektor pertambangan lambat laun juga semakin berkurang seiring dengan masuknya industri pertambangan pasir. Masyarakat Desa Mekarjaya khususnya, mau tidak mau harus mulai tersingkir akibat industri pertambangan pasir yang semakin berorientasi padat modal. Hal tersebut juga semakin diperparah dengan ketatnya persaingan dalam memperoleh pekerjaan, dengan jumlah penduduk sebanyak 7.604 jiwa di Desa Mekarjaya dan 9.185 jiwa untuk Desa Rancapaku, menjadikan persaingan dalam memperoleh pekerjaan di tingkat desa semakin sulit, dan tidak jarang sebagian masyarakat harus mencari pekerjaan hingga ke luar kota, diantaranya Garut, Bandung, atau bahkan hingga Jakarta untuk menjadi buruh kasar ataupun membuka warung kelontong.

\section{Kondisi Fisik}

Berbagai perubahan secara nyata telah terjadi pasca terjadinya erupsi Gunung Galunggung pada tahun 1982 -1983. Terlebih pada sebelum tahun 1982 masih banyak rumah warga yang merupakan rumah panggung, sehingga tidak jarang pada pasca erupsi ditemui rumah yang benarbenar hancur akibat tidak mampu menopang semburan abu dan pasir dari erupsi Gunung Galunggung.

Perbaikan dan pembersihan namun tidak hanya dilakukan oleh masyarakat, kondisi pasca erupsi Galunggung tersebut juga menjadi perhatian pemerintah daerah dan pemerintah pusat. Rehabilitasi kawasan ini akhirnya selesai dan memakan waktu hampir satu tahun oleh pemerintah dengan bantuan masyarakat, cukup banyak fasilitas desa yang diperbaharui dan dibuat, diantaranya adalah jalan dan tanggul. Seiring dengan prosesnya kawasan Gunung Galunggung menjadi primadona bagi pebisnis, karena selain berlimpahnya material pasir di kawasan ini wisata kawah Gunung Galunggung dan pemandian air panas Cipanas yang mulai dibuka pasca rehabilitasi erupsi Gunung Galunggung juga sangat menarik wisatawan. Pada akhirnya berbagai jalan-jalan yang dipergunakan untuk jalur kendaraan bermotor berlalu lalang mulai dibuka dan dikembangkan yang juga didukung oleh sebagian warga, bahkan sempat pernah ada jalur rel kereta api yang menghubungkan kawasan Gunung Galunggung sampai dengan stasiun Indihiang yang dimanfaatkan untuk mengangkut berbagai material pasir.

Disamping itu, fasilitas pendidikan maupun kesehatan di kedua desa dapat dikatakan cukup mumpuni. Dari tingkat pendidikan anak usia dini (PAUD) atau taman kanakkanak (TK) sampai dengan sekolah menengah atas (SMA) terdapat di kawasan ini, demikian halnya dengan Posyandu. Selain itu, secara khusus di Desa Mekarjaya memiliki pasar ikan yang juga sering dimanfaatkan oleh masyarakat untuk menjual berbagai hasil dari ternak ikan, diantaranya seperti ikan mas, mujaer, nila, hingga gurami. Pasar ikan ini kerap dipergunakan warga di Kecamatan Padakembang dan bahkan luar dari Kecamatan Padakembang untuk melakukan jual dan beli berbagai komoditas ikan tersebut.

\section{ANALISIS IDEOLOGI DAN PERANAKTORDALAM PERTAMBANGAN PASIR GALUNGGUNG}

\section{Aktor Masyarakat}

Berbicara tentang aktivitas pertambangan pasir di Gunung Galunggung, maka tidak akan lepas dari sejarah dan peran masyarakat lokal itu sendiri. Berawal dari pasca rehabilitiasi erupsi Gunung Galunggung pada tahun 1983, masyarakatlah yang memulai melakukan aktivitas pertambangan pasir untuk pertama kalinya. Kondisi pasca erupsi Gunung Galunggung menyebabkan lahan-lahan milik warga dipenuhi oleh material pasir, sehingga aktivitas pengerukan pasir sudah mulai dikenal warga ketika itu, namun lebih ditujukkan untuk membersihkan lahan-lahan atau pekarangan milik mereka. Seperti yang disebutkan oleh APH (55 tahun) yang merupakan warga asli Desa Mekarjaya:

"Pasca letusan, sawah, kolam, hingga rumah itu hancur karena hujan abu dan pasir. Tebalnya itu kurang lebih sampai $20 \mathrm{~cm}$. Kondisi itulah yang paling sulit, karena setelah bencana (letusan) itu kita perlu modal banyak untuk memperbaiki rumah. Tapi soal dana kembali jadi masalah, karena ketika itu sawah yang jadi andalan saja tertimbun. Tapi akhirnya ada yang mulai menjual pasir. Dari yang awalnya dibuang-buang di dalam tanah atau sungai oleh masyarakat, lama kelamaan masyarakat mulai mengikuti untuk dijual. Sejak itu pasir mulai dijual ke berbagai tempat, dan ternyata karena kualitas pasirnya yang baik, harganya pun dapat dijual cukup tinggi. Akhirnya hampir semua mengikuti, bahkan tidak jarang "juragan" sawah yang memiliki ratusan batal sampai menyewakan sawahnya untuk dikeruk material pasirnya."

Berdasarkan pemaparan bapak APH, lambat laun masyarakat mulai ada yang menjual pasir tersebut hingga keluar desa. Tidak jarang pasir ini juga dibeli oleh orang- 
orang yang umumnya juga pengusaha toko bangunan atau pebisnis yang mencari pasir dengan harga yang "miring". Bahkan, pembeli pasir tersebut kerap langsung mendatangi lokasi desa yang cukup parah tertimbun oleh pasir-pasir untuk mendapatkan harga yang lebih murah. Mulai sejak itu pula masyarakat di kawasan Gunung Galunggung mulai menyadari bahwa pasir yang menimbun hampir seluruh wilayah di desa mereka tersebut diburu dan memiliki nilai ekonomi tersendiri.

Bahkan menurut salah seorang warga, ketika itu ada sebagian masyarakat yang membentuk kelompokkelompok untuk melakukan penambangan pasir, walaupun hanya bermodalkan cangkul, wadah dan serokan, kelompok masyarakat tersebut bertahan cukup lama sebelum akhirnya tersingkir oleh industri penambangan pasir yang jauh lebih besar.

Masuknya industri pertambangan di desa ini pada akhirnya hanya menjadikan mereka sebagai pekerja, limpahan pasir yang awalnya menurut sebagian masyarakat mampu mereka manfaatkan untuk mensejahterakan mereka ternyata justru sebatas mensejahterakan para pemodal besar. Walaupun perusahaan tambang pada sebelum tahun 2000 lebih tergolong padat karya, namun faktanya tidak pernah ada masyarakat yang mampu mencapai titik kesejahteraan tersebut.

Memang menurut sebagian masyarakat apa yang terjadi pasca masuknya industri pertambangan pada tahun 2000 merupakan hal yang berdampak buruk bagi mereka. Berbeda ketika dahulu dimana pihak perusahaan masih menggunakan cara konvensional, industri yang masuk pasca tahun 2000 lebih tergolong sebagai industri padat modal, sehingga dampak positif yang ditimbulkan pun tergolong minim, bahkan dalam kaitannya dengan peluang kerja, hanya sedikit masyarakat dari Desa Mekarjaya yang pada saat itu bekerja di perusahaan tambang. Justru secara nyata, berbagai dampak negatif terus mulai mereka rasakan, dari kerusakan ekologi hingga implikasinya pada sosial maupun ekonomi.

Kondisi tersebut pada akhirnya membuat berbagai lapisan masyarakat mulai melakukan penolakan atas kehadiran perusahaan tambang pasir. Penolakan tidak hanya dilakukan oleh masyarakat sekitar kawasan Gunung Galunggung, namun juga hingga masyarakat yang bukan merupakan warga Galunggung. Salah satu kelompok atau basis masyarakat lokal yang turut berkontribusi untuk melakukan advokasi terhadap pihak pemerintah dan perusahaan tambang diantaranya adalah Kelompok Pembenihan Ikan Mekar Saluyu. Bahkan pada tahun 2013 lalu, kelompok pembenihan ikan ini dan didukung dengan sebagian masyarakat di Desa Mekarjaya, telah berhasil menandatangani pernyataan kesepakatan antara pihak masyarakat, perusahaan tambang dan juga pemerintah terkait dengan dampak ekologis yang disebabkan oleh aktivitas penambangan pasir. Beberapa poin kesepakatan yang melibatkan masyarakat, pemerintah, dan empat orang perwakilan dari perusahaan tambang tersebut diantaranya adalah bahwa pihak perusahaan tambang harus secara nyata menganggulangi persoalan dampak dan limbah tambang yang menyebabkan degradasi kualitas lingkungan, dengan membuat saluran irigasi baru ataupun membuat kantong limbah.

Walaupun surat kesepakatan tersebut telah ditandatangani seluruh pihak terkait, dan menyatakan jika terdapat segala ketidaksesuaian atau pelanggaran dari poin-poin perjanjian tersebut maka pihak perusahaan tambang dapat dituntut secara hukum, namun hingga saat ini belum ada realisasi yang dapat memuaskan seluruh pihak. Bahkan lambat laun, penolakan kehadiran perusahaan tambang tidak hanya sebatas pada penekanan permasalahan lingkungan, namun juga implikasinya terhadap aspek sosial hingga tuntutan ekonomi masyarakat.

Masyarakat kawasan Gunung Galunggung yang pada awalnya menjaga keseimbangan alam dan ekosistem Gunung Galunggung secara baik dengan menghargai nilai lingkungan serta sumber daya alam di dalamnya biocentrism), mau tidak mau pada dewasa ini justru memperoleh hasil yang sebaliknya, berupa degradasi kualitas ekosistem yang diakibatkan oleh dominasi kekuatan industri tambang pasir yang semakin berkembang dan besar (Tabel 1). Merupakan suatu ironi pula ketika pada awalnya banyak masyarakat yang mengaharapkan kesejahteraan dengan kehadiran perusahaan tambang pasir tersebut, namun justru harus dihadapkan dengan fakta jika industri tersebut malah membuat eksistensi mata pencaharian dan ekosistem mereka semakin terancam.

\section{Aktor Swasta}

Sebagai kawasan pertambangan yang memiliki sumber daya pasir yang berlimpah, kawasan Gunung Galunggung dianggap sebagai lahan strategis yang sejak lama telah menjadi incaran berbagai industri besar. Bahkan seusai rehabilitasi kawasan pasca erupsi pada tahun 1983, mulai marak industri pertambangan pasir di kawasan ini, mulai yang berskala kecil yang merupakan hasil inisiasi dari masyarakat lokal, hingga yang berskala besar yang merupakan hasil investasi pejabat nasional pada era itu. Selain itu, pasir Galunggung yang dianggap memiliki kualitas terbaik pada eranya, menurut sebagian informan dipergunakan untuk menyokong program pembangunan yang kala itu sedang digencarkan oleh pemerintah orde baru.

Aktivitas yang dilakukan masyarakat itu namun pada akhirnya mulai menarik masuk berbagai perusahaan atau industri tambang yang berskala lebih besar. Pada sekitar setelah tahun 1984 mulai masuklah industri tambang pasir pertama di kawasan Gunung Galunggung, diantaranya PT HS dan PT BO. Kedua perusahaan tersebut juga masih menggunakan cara konvensional dalam melakukan aktivitas penambangan. Selain itu, kedua perusahaan ini juga masih memanfaatkan hampir 80 persen tenaga kerja masyarakat lokal, sehingga tergolong sebagai usaha yang padat karya. Seperti yang disebutkan oleh DDG (52 tahun) yang merupakan salah satu pegawai pemerintah di Desa Mekarjaya:
"Ketika jaman PT HS atau PT BO itu masyarakat seolah semakin terbantu. Mereka itu sama sekali belum menggunakan „,beku" (,,beku" merupakan istilah lokal untuk menyebut buldozer), jadi ada kerjasama antara pihak perusahaan dengan masyarakat. Sehingga kalau ketika itu mungkin istilahnya perusahaan sebagai pihak yang memberi modal untuk masyarakat. Jadi masyarakat tidak keberatan walaupun sudah muncul istilah "perusahaan tambang", berbeda dengan sekarang." 
Pasca masuknya PT HS dan PT BO di kawasan Gunung Galunggung, sebagian besar masyarakat mulai mengetahui bahwa pasir Galunggung ternyata memiliki nilai jual yang tinggi. Masyarakat lokal yang awalnya secara bebas melakukan aktivitas penambangan secara individual namun pada akhirnya mulai kalah dan secara perlahan tersingkir oleh industri-industri skala besar yang juga masuk untuk mengeruk sumber daya alam pasir Galunggung tersebut.

Terlebih pasca pembangunan rel kereta api yang langsung menghubungkan antara Gunung Galunggung dengan stasiun kereta api yang berada di daerah Indihiang, Kota Tasikmalaya. Rel kereta tersebut dimanfaatkan untuk membawa material pasir dengan jumlah yang sangat besar. Hal tersebut juga mengindikasikan kualitas pasir Galunggung yang memang memiliki pangsa pasarnya tersendiri. Menurut salah seorang informan, rel kereta tersebut dibangun oleh PT BO, perusahaan yang juga merupakan milik salah satu anggota dari keluarga cendana, keluarga yang menguasai rezim pemerintahan kala itu. Pasir-pasir yang diangkut tersebut juga dianggap sebagai cikal bakal berbagai pembangunan gedung hingga jalan tol di kota Jakarta.

Setelah era pertambangan dengan cara konvensional usai, pada pasca reformasi atau tepatnya sekitar tahun 2000 mulai masuk berbagai perusahaan yang menggunakan alat berat untuk melakukan pengerukan pasir, termasuk di Desa Mekarjaya. Seperti yang juga disebutkan oleh DDG (52 tahun):

"Setelah sekitar tahun 2000, itu baru mulai banyak masuk yang menggunakan ,, beku". Ada CV PG, CV $F R, C V S A$, dan yang terakhir PT KR dan $C V A S$. Walaupun dapat dikatakan perusahaan tidak sebesar PT HS atau PT BO, tapi ternyata dampak yang ditimbulkan lebih parah untuk masyarakat."

Pasca masuknya perusahaan-perusahaan tersebut, kawasan Gunung Galunggung seolah semakin menjadi wilayah yang hanya dimanfaatkan untuk diambil keuntungannya saja. Pihak swasta yang melakukan pengerukan secara besar-besaran ini keberadaannya semakin diperparah ketika mereka mengabaikan berbagai hal yang seharusnya menjadi tanggung jawab dari perusahaan, diantaranya seperti melakukan pengelohan limbah serta tanggung jawab sosial dan lingkungan lainnya. Hal seperti itu tidak pernah secara tegas dan teratur dilakukan oleh pihak pertambangan, bahkan tuntutan masyarakat untuk melakukan pengelolaan limbah seolah tidak pernah memiliki lanjutannya hingga kini, hal tersebut tentunya tidak sesuai dengan dampak yang ditimbulkan dengan keuntungan yang diperoleh oleh pihak perusahaan pertambangan.

Berdasarkan penjabaran tersebut, dapat diketahui jika pada dasarnya orientasi profit swasta yang menjadikan sumber daya alam hanya sebatas untuk pemenuhan kebutuhan manusia (antroposentris) menyebabkan adanya ketidakadilan yang harus diterima oleh masyarakat (Tabel 1). Terlebih mengingat kawasan ini telah dikeruk sejak tahun 1984, seharusnya perjuangan masyarakat atas kepentingan serta tuntutan kesejahteraan mereka harus menjadi aspek vital yang diperhatikan oleh penyelenggara industri maupun seluruh stakeholders yang terkait.

\section{Aktor Pemerintah}

Pemanfaatan objek tambang pasir di kawasan Gunung Galunggung mulai masuk di kawasan ini sejak tahun 1984. Secara konstitusional, pada era tersebut Indonesia memiliki satu undang-undang yang secara khusus membahas tentang ketentuan-ketentuan pokok lingkungan hidup, yakni dalam Undang-Undang No. 4 tahun 1982 Didalamnya terdapat butir pasal yang selanjutnya dikenal dengan Analisis Dampak Lingkungan (AMDAL). Walaupun berfungsi sebagai pertimbangan utama untuk perizinan kegiatan atau usaha, pada implementasinya tidak jarang AMDAL hanya tercantum sebagai formalitas dan tidak dilaksanakan sesuai amanatnya. Seperti halnya yang disebutkan oleh RHM (60 tahun) yang dulunya merupakan pegawai pemerintah Desa Mekarjaya:

\section{" Dulu itu sepertinya tidak ada AMDAL. Perusahaan masuk ya langsung saja, mungkin saya kurang paham prosesnya bagiamana, tapi saya juga sebagai masyarakat tidak pernah dengar yang seperti itu, apalagi kalau tahu di syarat AMDAL harus persetujuan masyarakat. Hal seperti itu tidak pernah ada."}

Lebih lanjut, bahkan aktivitas seperti pertambangan pasir skala besar yang pernah terjadi di kawasan Gunung Galunggung pada era orde baru, sama sekali hampir tidak ada bekas rekam jejaknya. Menurut sebagian besar masyarakat, hal tersebut terjadi karena hegemoni politik orde baru yang menyebabkan seluruh tindakan pejabat adalah benar masih melekat dengan pemikiran masyarakat kala itu. Mereka menganggap walaupun perusahaanperusahaan tersebut datang tanpa izin dan tidak transparan terhadap masyarakat, selama itu didukung oleh pihak pemerintah, maka hal tersebut merupakan hal yang harus juga mereka dukung. Terlebih bagi sebagaian masyarakat yang berada di lokasi sekitar pertambangan kala itu, terbukanya peluang kerja yang baru merupakan suatu insentif ekonomi yang dianggap sangat menguntungkan.

Namun masuknya industri pertambangan padat modal yang ditandai dengan pemanfaatan alat-alat berat yang mulai masuk di kawasan Kecamatan Padakembang pada tahun 2000-an, secara perlahan semakin membatasi peluang kerja masyarakat di sektor pertambangan. Hal tersebut semakin diperparah dengan adanya berbagai penyimpangan yang tidak hanya pada tahap proses perizinan, namun bahkan hingga pelaksanaannya. Menurut data Kabupaten Tasikmalaya dalam Angka pada tahun 2013, di wilayah Kecamatan Padakembang tidak terdapat satu pun industri yang termasuk pada golongan sedang atau besar (industri yang memiliki pekerja lebih dari 20 orang), namun sebagian besar masyarakat justru menyatakan pernyataan yang menyatakan sebaliknya, dimana pada tahun 2013 mereka masih dapat melihat aktivitas pertambangan hingga truk yang berlalu lalang membawa material pasir Gunung Galunggung.

Pernyataan diatas memang sesuai dengan apa yang disebutkan oleh sebagian besar informan, industri tambang yang pada saat ini ada di Kecamatan Padakembang khususnya Desa Mekarjaya merupakan industri berskala besar yang jelas-jelas memiliki tenaga kerja lebih dari 20 orang. Bahkan menurut pemerintah Desa Mekarjaya sendiri, CV AS yang merupakan salah satu industri tambang berskala besar di kawasan Gunung 
Galunggung telah melakukan aktivitas pertambangannya sejak tahun 2006. Bahkan disebutkan, CV AS baru saja memperpanjang kontraknya pada tahun 2011 lalu. Hal tersebut setidaknya menunjukkan adanya perbedaan fakta yang tertulis dalam data dengan apa yang ada di lapangan.

Isu aktivitas penambangan pasir Galunggung secara ilegal atau tanpa izin memang sudah sering didengar warga sejak lama. Tetapi baik pemerintah tingkat desa maupun di tingkat kecamatan seolah saling menghindar dan cenderung beralasan permasalahan penambangan merupakan permasalahan kompleks yang dari aspek perizinannya lebih banyak diurus oleh pemerintah pusat. Seperti yang disebutkan oleh YYT (52 tahun) seorang peternak ikan di Desa Mekarjaya yang juga cukup aktif. dalam menuntut hak-hak masyarakat yang terkena dampak dari aktivitas penambangan pasir:

"Saya dan teman-teman dari kelompok pembenihan ikan itu sudah bukan sekali atau dua kali datang ke kantor desa. Tapi tetap saja hasilnya sama, ketika awal tahun kemarin kita baru kesana dan meminta surat tentang perizinan perusahaan tambang, tetapi tidak pernah ada. Padahal seharusnya izin menambang di daerah kita, di wilayah kita, ya minimal harus jelaslah suratnya ke masyarakat, karena itu hak masyarakat sebenarnya, tapi ya kenyataannya berbeda. Disini pokoknya uang yang berkuasa."

Tabel 1. Analisis aktor pertambangan pasir Gunung Galunggung

\begin{tabular}{|c|c|c|c|c|}
\hline No. & Aktor & Ideologi & Peran & Fakta \\
\hline 1 & $\underset{\text { yarakat }}{\mathrm{m}}$ & $\begin{array}{l}\text { kesejahter- } \\
\text { aan, } \\
\text { populis, } \\
\text { biocentris }\end{array}$ & $\begin{array}{l}\text { 1.penambang } \\
\text { konvensional } \\
\text { 2.korban kebija- } \\
\text { kan } \\
\text { 3. advokasi }\end{array}$ & $\begin{array}{l}\text { suara masyarakat } \\
\text { yang minor } \\
\text { m e n e ba b b a n } \\
\text { masyarakat ters- } \\
\text { ingkir } \\
\text { dan berada pada } \\
\text { posisi inferior atas } \\
\text { tekanan dan dom- } \\
\text { inasi pihak swasta } \\
\text { dan pemerintah }\end{array}$ \\
\hline 2 & swasta & $\begin{array}{l}\text { profit, } \\
\text { a n tro p o - } \\
\text { sentris }\end{array}$ & $\begin{array}{l}\text { 1.pelaku industri } \\
\text { pertambangan } \\
\text { 2. penyuplai dan } \\
\text { pendistribusi } \\
\text { kebutuhan pasir } \\
\text { konsumen } \\
\text { 3.tanggung jawab } \\
\text { sosial kepada } \\
\text { masyarakat }\end{array}$ & 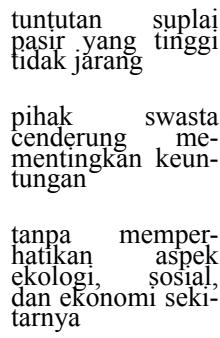 \\
\hline 3 & $\begin{array}{l}\text { pemerin- } \\
\text { tah }\end{array}$ & $\begin{array}{l}\text { profit, } \\
\text { a n tro p o - } \\
\text { sentris, } \\
\text { evelop- } \\
\text { mentalism }\end{array}$ & $\begin{array}{l}\text { 1.mengatur reg- } \\
\text { ulasi } \\
\text { 2. memberikan } \\
\text { gan penamban- } \\
\text { 3. me lak kukan } \\
\text { pengawasan kon- } \\
\text { trak dan aktivitas } \\
\text { penambangan }\end{array}$ & $\begin{array}{l}\text { lemahnya regulasi } \\
\text { ditingkat daerah } \\
\text { dan } \\
\text { law enforcement } \\
\text { m e n y ba b kan } \\
\text { banyaknya celah } \\
\text { penyimpangan } \\
\text { yang dimanfaat- } \\
\text { kan oknum pe- } \\
\text { merintah untuk } \\
\text { melanggengkan } \\
\text { kepentingan dan } \\
\text { ego elit }\end{array}$ \\
\hline
\end{tabular}

Berbagai fakta dan data yang menyatakan adanya penyimpangan tersebut setidaknya mampu memperlihatkan arah tendensi pihak pemerintah terkait dengan permasalahan pertambangan di kawasan
Gunung Galunggung. Pemerintah yang seharusnya mampu merepresentasikan kekuatan populis justru malah terksesan bertindak sebaliknya dengan otoritas yang dimiliki. Bahkan dapat dikatakan orientasi pemerintah dalam kasus ini lebih cenderung mirip dengan pihak swasta yang mengedepankan keuntungan elite semata.

Cara pandang pemerintah yang lebih cenderung bertumpu pada benefit, developmentalism, dan antroposentris atau cara pandang yang menganggap alam hanya sebagai pemenuhan kebutuhan manusia, ini merupakan cara pandang yang setidaknya telah merugikan masyarakat yang berada di kawasan Gunung Galunggung selama kurang lebih tiga puluh tahun (Tabel 1). Selain itu, berbagai fakta atas kondisi pemerintah yang tidak berpihak terhadap kepentingan masyarakat secara umum terbukti dengan tidak adanya pengawasan perusahaan pertambangan secara berkala dan kebijakan afirmatif yang dianggap mampu mendorong tujuan utama masyarakat yang berada di sekitar kawasan pertambangan, yakni tujuan dalam memperoleh kesejahteraan.

\section{ANALISIS DAMPAK PERTAMBANGAN PASIR Dampak Ekologi}

Permasalahan ekologi yang terdapat di kawasan Gunung Galunggung mulai terlihat pasca masuknya aktivitas pertambangan pasir skala industri pada sekitar tahun 1984. Pada saat itu, permasalahan dimulai ketika dibukanya berbagai lahan atau kawasan hutan yang diperuntukan untuk konsesi pertambangan. Hal ini semakin diperparah dengan banyaknya sawah atau lahan warga yang dijual kepada pihak perusahaan tambang. Dengan alasan "membersihkan" material pasir yang memang hampir menimbun seluruh sawah dan pekarangan milik warga kala itu, ditambah dengan tawaran bayaran untuk harga sawah atau pekarangan yang tinggi, banyak masyarakat di Desa Mekarjaya yang langsung tergiur untuk menjual lahan miliknya. Sedangkan respons berbeda terdapat di Desa Rancapaku, dimana hampir tidak ada lahan yang dijual secara permanen untuk diperjual belikan. Kondisi yang terjadi di Desa Mekarjaya tersebut pada akhirnya menurut sebagian masyarakat menyebabkan "keasrian" dari Gunung Galunggung berkurang dari hari ke hari, dari jumlah pohon yang semakin menipis, atau bahkan suara-suara binatang yang dulu dapat dengan mudah terdengar di berbagai sudut desa, pada saat ini sudah sangat sulit untuk ditemukan.

Selain itu, salah satu aspek yang paling krusial dan menyusun keseimbangan ekosistem di Desa Mekarjaya maupun di Desa Rancapaku adalah air. Air yang bersih ketika dahulu dapat dengan mudah diperoleh oleh masyarakat melalui aliran Sungai Cikunir maupun cabang anak sungai yang juga kerap dialirkan secara sengaja untuk kepentingan sawah, kolam ternak ikan dan lain sebagainya. Namun masyarakat di kedua desa tersebut harus merasakan permasalahan yang lambat laun semakin mengancam mereka, hal tersebut antara lain karena air yang dahulu berlimpah pada saat ini sudah berbalik menjadi "aliran limbah" yang tidak dapat mereka kendalikan.

Sungai yang menjadi salah satu sumber penghidupan warga tersebut semakin mengalami degradasi kualitas dan fungsinya. Pada saat ini saja, masyarakat bahkan tidak dapat lagi memanfaatkan air yang mengalir melalui 
Sungai Cikunir, karena aliran sungai tersebut juga telah membawa aliran limbah yang berasal dari kawasan pertambangan di Desa Mekarjaya, yang terletak di sekitar kawasan hulu Gunung Galunggung. Pasalnya, perusahaan pertambangan sama sekali tidak membuat kantong limbah ataupun upaya penanggulangan limbah secara signifikan. Bahkan seolah tidak peduli dan cenderung mengabaikan atas fakta degradasi kualitas lingkungan yang terjadi. Implikasinya, tidak hanya air bersih yang sulit diperoleh bagi masyarakat, ancaman bencana seperti banjir dan longsor juga semakin nyata dirasakan masyarakat.

Seperti yang telah disebutkan sebelumnya, selain menjadi keruh dan dipenuhi pasir atau bebatuan halus lainnya, Sungai Cikunir juga mengalami penyusutan dan pendangkalan. Bahkan menurut seorang informan, penyusutan Sungai Cikunir kurang lebih sampai 10 meter hingga pada tahun 2014. Kondisi tersebut pada akhirnya menyebabkan peluapan air hingga mencapai ke rumahrumah warga, khususnya warga yang berada di Desa Rancapaku. Pasalnya, banyak kawasan kampung atau dusun di Desa Rancapaku yang tepat bersebelahan dengan Sungai Cikunir. Seperti yang disebutkan oleh Bapak ASD (50 tahun):

\section{“ Kalau di Desa Mekarjaya sebenarnya (bencana) longsor atau banjir itu hampir tidak pernah. Tapi longsor beberapa bulan yang lalu sempat ada di daerah dekat Dusun Karangdan. Tetapi untungnya tidak terlalu parah. Kalau banjir baru bulan Meret lalu tanggal 19 kalau tidak salah, lokasinya juga di Dusun Karangdan, banjir saat itu bahkan sampai ke pesantren yang dibawahnya. Sedangkan kalau daerah Desa Rancapaku, banjirnya cukup sering terjadi, karena banyak rumah dekat Sungai Cikunir atau Cikunten situ, sehingga kalau sedang hujan besar langsung membanjiri rumah dan juga sawah warga"}

Berdasarkan pernyataan tersebut, dampak negatif ekologi yang ditimbulkan akibat aktivitas pertambangan tidak hanya berdampak pada bencana yang mengancam lingkungan atau rumah mereka, namun bahkan hingga berdampak pada mata pencaharian masyarakat, khususnya petani di Desa Rancapaku yang sawahnya juga kerap tergenang air dari luapan Sungai Cikunir.

Dampak ekologi lainnya yang menonjol dan diakibatkan oleh pertambangan pasir adalah jalanan yang rusak serta polusi melalui udara. Jalan utama di Desa Mekarjaya merupakan jalan yang selain dimanfaatkan oleh warga namun dimanfaatkan juga oleh truk-truk pengangkut material pasir yang selama hampir 24 jam terus berlalulalang. Jalan ini pun dapat dikatakan rusak parah, selain membahayakan masyarakat, jalanan yang rusak ini juga membuat mobilitas masyarakat menjadi terhambat.

Terlebih truk pengangkut pasir kerap membawa muatan pasir yang berlebih, sehingga tidak jarang banyak debudebu dan pasir dari truk pengangkut berterbangan hingga mencemari lingkungan dan teras rumah warga, atau bahkan hingga terhirup warga dan menyebabkan gejalagejala infeksi saluran pernapasan. Seperti yang disebutkan oleh Ibu LSR (47 tahun) seorang pedagang di kawasan jalan utama Desa Mekarjaya:

Masyarakat disini mungkin sudah sampai ,terbiasa" dengan debu, Tapi sebenarnya bagaimana juga dibalik hati masing-masing pasti "risih", apalagi itu debu kan sangat mengganggu banyak orang, tapi mau mengeluh juga percuma..

Lebih lanjut, sebagai reaksi atas berbagai keadaan tersebut, sebagian masyarakat di Desa Mekarjaya khususnya daerah Dusun Cikembang membuat "jalur bebas truk", yakni melarang truk yang bermuatan pasir untuk lewat. Bahkan secara khusus masyarakat di kampung Babedahan, Desa Mekarjaya membuat portal yang bertujuan untuk menghalangi truk masuk ke kawasan kampung. Hal tersebut juga serupa seperti yang dilakukan oleh masyarakat di Desa Rancapaku, dimana masyarakat dan pihak pemerintah sama-sama menyepakati larangan untuk truk pengangkut pasir lewat kawasan desa mereka. Hasilnya, kondisi jalanan sepanjang Desa Rancapaku cukup berbanding terbalik dengan kondisi jalan utama di Desa Mekarjaya.

Berdasarkan berbagai pernyataan diatas, dapat disimpulkan bahwa dampak ekologi yang dirasakan masyarakat baik pada Desa Mekarjaya ataupun Desa Rancapaku memiliki penekanan pada poin-poin yang berbeda. Hal tersebut pada akhirnya menghasilkan persepsi mayoritas masyarakat baik pada Desa Mekarjaya dan Desa Rancapaku cenderung berada pada kategori sedang.

Kondisi ini ditunjukkan dengan masyarakat Desa Mekarjaya yang lebih merasakan dampak ekologiaktivitas pertambangan pasir pada aspek-aspek berikut, yakni jalanan yang rusak, polusi melalui udara, kebisingan, dan konversi lahan untuk fungsi pertambangan yang menyebabkan lahan hijau semakin berkurang. Sedangkan pada masyarakat Desa Rancapaku, lebih merasakan dampak ekologi aktivitas pertambangan pasir pada aspek berikut, diantaranya adalah air bersih yang semakin sulit diperoleh dan ancaman terhadap bencana alam seperti longsor dan banjir.

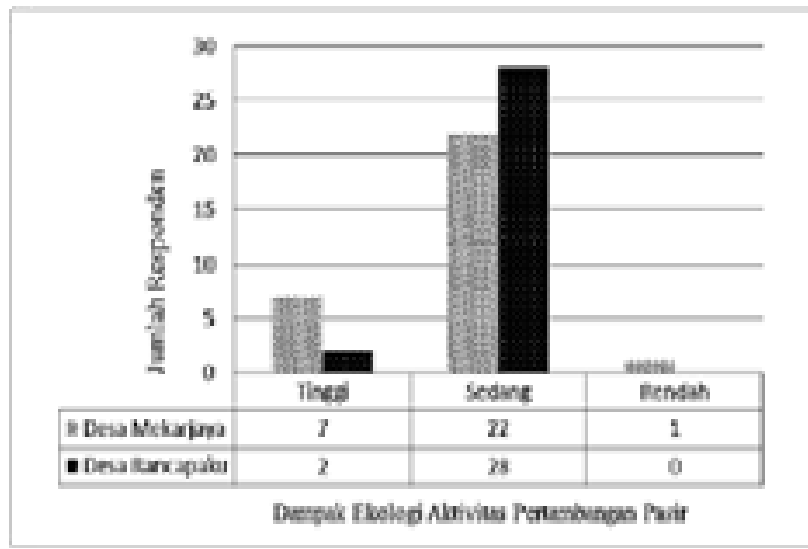

Gambar 2. Perbandingan persepsi responden terhadap dampak ekologi pertambangan pasir

\section{Dampak Sosial}

Masyarakat sebagai suatu kesatuan yang dinamis, tentunya dapat terpengaruh oleh berbagai perubahan kondisi yang terjadi di lingkungannya. Demikian halnya 
dengan masyarakat di Desa Mekarjaya dan Desa Rancapaku, keberadaan perusahaan pertambangan pasir pun ditanggapi berbeda oleh sebagian masyarakat di kedua desa tersebut. Dimana untuk masyarakat Desa Mekarjaya, mereka cenderung merespons keberadaan perusahaan pertambangan pasir dengan respons yang netral, berbeda dengan masyarakat Desa Rancapaku yang cenderung merespons keberadaan perusahaan pertambangan pasir dengan respons yang negatif.

Polarisasi masyarakat ini secara nyata terjadi karena beberapa alasan, diantaranya karena bagi sebagian masyarakat Desa Mekarjaya, kehadiran perusahaan pertambangan telah membawa manfaat positif yang tidak dapat hanya dilihat dalam bentuk "fisik", karena terbukanya peluang kerja baru di sektor pertambangan, ataupun peluang kerja baru bagi pengusaha warung makan atau kelontong di sekitar lokasi pertambangan, merupakan salah satu diantara beberapa manfaat yang di bawa langsung oleh pihak perusahaan masyarakat. Belum lagi seperti bantuan sosial yang kerap langsung diberikan oleh pihak pertambangan. Seperti yang disebutkan oleh ASD (50 tahun):

\section{"Masyarakat disini memang bingung, mau dibilang merasa rugi ya rugi, untung ya untung (dengan keberadaan perusahaan tambang). Terlebih disini kalau ada pembangunan masjid, sampai kemarin itu kantor desa juga dapat sumbangan dari perusahaan tambang. Pokoknya kalau untuk pembangunan atau sosial, perusahaan tambang pasti ngasih, jadi mau bagimana juga jadi untung ke masyarakat ".}

Namun kondisi yang berbeda dapat ditemui pada masyarakat Desa Rancapaku, menurut sebagian besar masyarakat, perusahaan tambang hanya cenderung mementingkan kepentingan bisnis, apa yang seharusnya menjadi tanggung jawab perusahaan seperti programprogram lingkungan ataupun pemberdayaan masyarakat lokal tidak pernah ada yang terealisasi. Selain itu, mereka pun menganggap mereka tidak pernah ikut dilibatkan dalam proses perizinan seperti AMDAL (atau UKL-UPL) oleh pihak perusahaan tambang pasir, padahal mereka juga menjadi pihak yang mau tidak mau merasakan dan menanggung dampak-dampak negatif yang diakibatkan oleh aktivitas pertambangan pasir tersebut.

Lebih lanjut, kondisi yang dialami oleh kedua desa tersebut juga dapat dilihat terkait dengan respons ekologi politik ataupun konflik yang terjadi. Namun terdapat perbedaan di kedua desa, dimana keduanya memiliki tensi dan bentuk konflik yang berbeda. Dengan kondisi sebagian masyarakat Desa Mekarjaya yang "menerima" keberadaan perusahaan pertambangan, respons yang ditunjukkan pun lebih terlihat kompromistik. Dalam artian masyarakat memang kerap melakukan protes untuk menuntut pertanggung jawaban perusahaan pertambangan terkait berbagai dampak yang ditimbulkan, namun dalam bentuk seperti penggunaan surat, ruang publik, spanduk, dll. Masyarakat dari Desa Mekarjaya tidak terlalu terlibat dengan aktivitas protes massa yang ditunjukkan dengan mobilisasi besar-besaran atau yang mengarah pada bentuk radikal. Sedikit berbeda dengan kondisi tersebut, masyarakat Desa Rancapaku pernah beberapa kali melakukan protes dengan mengadakan demonstrasi atau long-march yang diikuti bahkan oleh ibu-ibu dan anak-anak. Bahkan menurut seorang informan, kala itu masyarakat pernah melakukan mobilisasi ke lokasi pertambangan dan melakukan pelemparan batu ke alatalat berat perusahaan tambang. Respons tersebut memang beralasan, pasalnya protes yang dilakukan warga

selama ini tidak pernah mendapat tanggapan yang serius dari pihak pemerintah ataupun perusahaan tambang. Seperti yang juga disebutkan oleh ibu LSR (47 tahun):

"Kalau dari jaman dulu demo mungkin sudah ada puluhan kali. Bahkan dulu bukan cuma warga sini yang ikut berdemo. Tahun 2010 - 2011 banyak juga orang luar yang kesini untuk tanya-tanya tentang tambang, seperti wartawan (dan juga lembaga swadaya masyarakat). Tapi akhrinya sama-sama saja, sampai sekarang juga tetap saja perusahaan tambang beroprasi. Malah sepertinya semakin "menjadi"."

Memang pada dasarnya berbagai upaya telah dilakukan oleh masyarakat baik di Desa Mekarjaya, Desa Rancapaku atau bahkan dari luar kedua desa tersebut untuk menuntut hak-hak yang seharusnya masyarakat peroleh. Karena memang bagi sebagian masyarakat, masyarakat Desa Rancapaku khususnya kehadiran perusahaan tambang telah secara nyata merebut hak-hak mereka, seperti hak atas lingkungan yang nyaman dan hak atas air bersih.

Lebih lanjut, dampak dari aktivitas pertambangan pasir tidak hanya menyentuh pada tataran fisik, namun juga jauh bahkan hingga cara pandang masyarakat terhadap lingkungannya. Khususnya untuk masyarakat Desa Rancapaku, apatisme masyarakat terhadap Sungai Cikunir juga secara jelas ditunjukkan dengan banyaknya masyarakat yang membuang sampah di aliran sungai ini. Karena menurut mereka sungai yang pada awalnya sangat jernih dan deras ini memang sudah rusak dan tidak dapat dimanfaatkan lagi pasca kehadiran perusahaan tambang.

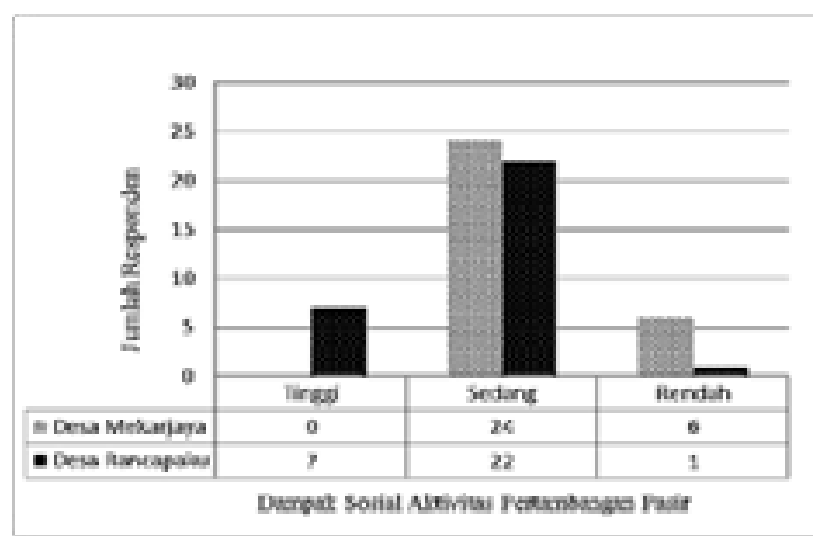

Gambar 3. Perbandingan persepsi responden terhadap dampak sosial pertambangan pasir

Berdasarkan pernyataan diatas dapat disimpulkan bahwa keberadaan perusahaan pertambangan juga telah membawa dampak sosial yang nyata bagi masyarakat Desa Mekarjaya dan Desa Rancapaku. Walaupun akumulasi kecenderungan respons masyarakat terkait dengan dampak sosial aktivitas pertambangan pasir berada pada kategori sedang, tetapi setidaknya terdapat tujuh orang dari Desa Rancapaku yang termasuk dalam ketegori tinggi dalam merespons negatif 
pernyataan- pernyataan terkait dengan dampak sosial yang ditimbulkan dari aktivitas pertambangan pasir.

Hasil tersebut diantaranya dikarenakan masyarakat Desa Rancapaku tidak memiliki hubungan ataupun ketergantungan langsung dengan pihak pertambangan, sehingga muncul istilah "nothing to lose", sehingga representasi tindakan mereka lebih bebas dan tidak terikat oleh nilai-nilai tertentu, bahkan tidak jarang mengarah pada sikap yang radikal ketika menunjukkan responsnya terhadap perusahaan pertambangan. Berbeda dengan masyarakat dari Desa Mekarjaya, yang secara langsung maupun tidak langsung memiliki kecenderungan "ketergantungan" ekonomi dan juga hubungan sosial dengan pihak-pihak yang berada di sektor pertambangan, sehingga responsnya cenderung berada pada posisi netral dan tertutup.

\section{Dampak Ekonomi}

Keberadaan industri di desa tentunya akan dapat berpengaruh kuat terhadap aktivitas ekonomi desa secara umum. Selain diharapkan mampu menyerap tenaga kerja, karena dalam konteks pertambangan memang terdapat berbagai proses yang cukup panjang didalamnya, dari penggalian hingga pengangkutan hasil tambang yang membutuhkan jumlah pekerja yang banyak. Keberadaan aktivitas tambang pasir, juga diharapkan mampu memberikan dampak positif untuk menggerakkan motor ekonomi desa, seperti dengan adanya program kemitraan, program pemberdayaan, dan lain sebagainya.

Namun pada dasarnya hal tersebut juga kembali pada pihak industri itu sendiri, karena tidak jarang industri hanya mementingkan keuntungan dan bahkan sama sekali tidak memperhatikan kepentingan masyarakat yang berada di sekitar kawasan industri tersebut. Selain itu, tentunya peran serta pemerintah yang berpihak pada masyarakat juga menjadi landasan agar tidak terjadi penyimpanganpenyimpangan yang dilakukan oleh pihak swasta. Secara garis besar, keberadaan aktivitas pertambangan pasir di Desa Mekarjaya juga dianggap sebagian masyarakatnya membawa dampak positif, seperti yang dapat dilihat pada Gambar 4.

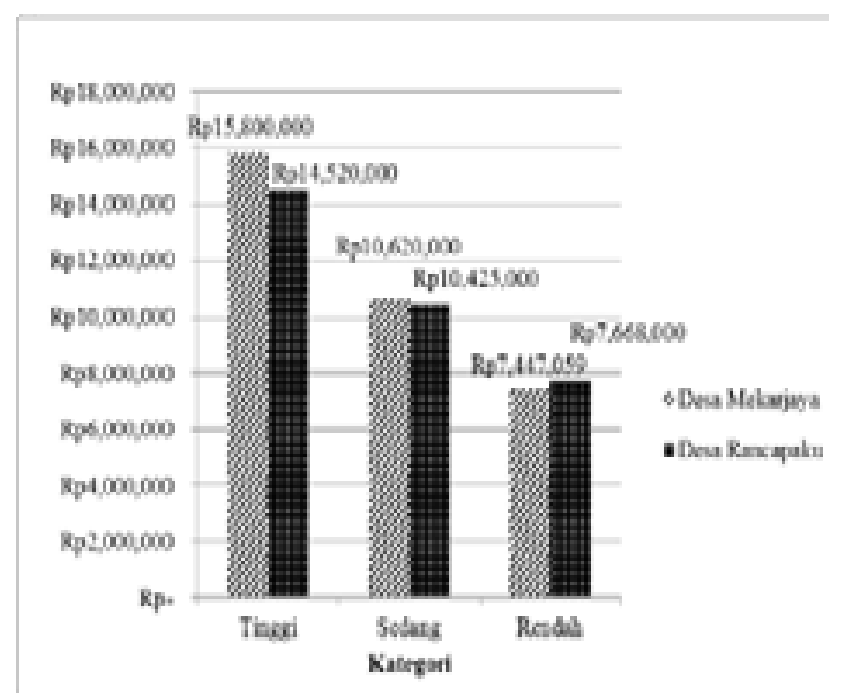

Gambar 4. Rata-rata pendapatan rumah tangga responden April 2013 - April 2014
Berdasarkan Gambar 4, dapat dilihat bahwa rata-rata pendapatan rumah tangga responden di Desa Mekarjaya cenderung lebih tinggi dibanding dengan Desa Rancapaku. Walaupun hanya selisih tipis, dan responden yang dipilih memiliki latar belakang pekerjaan yang beragam dari buruh kasar hingga wiraswasta, namun kondisi tersebut juga mengindikasikan adanya kontribusi ekonomi secara langsung maupun tidak langsung atas keberadaan sektor pertambangan di Desa Mekarjaya.

Seperti yang juga disebutkan salah seorang responden di Desa Mekarjaya, selain bekerja menjadi supir ojek, beliau juga kerap kali dipanggil untuk menjadi supir truk pengangkut pasir temporer, tentu saja hal tersebut berpengaruh juga dalam meningkatkan pendapatannya. Selain itu ramainya kawasan sekitar lokasi tambang dan jalur yang dilalui truk pengangkut pasir, membuat beberapa warga membuka warung makan atau kelontong yang kerap didatangi oleh para pekerja tambang.

Namun kondisi yang berbeda dapat kita lihat pada Desa Rancapaku, dimana kawasan ini tidak terdapat aktivitas pertambangan dan jalurnya yang juga tidak dilewati oleh truk pengangkut pasir. Tidak terlalu banyak masyarakat yang membuka warung makan ataupun warung kelontong, bahkan seperti yang disebutkan salah seorang informan, jika tepat siang hari kawasan Desa Rancapaku ini dapat dikatakan cukup sepi.

Bahkan lebih lanjut, disebutkan juga jika aktivitas ekonomi masyarakat pasca keberadaan perusahaan tambang menunjukkan trend kearah negatif. Selain karena mobilitas masyarakat yang terhambat karena jalan utama Desa Mekarjaya yang menjadi salah satu penghubung ke Tasikmalaya danSingaparna rusak parah dan dipenuhi debu-debu serta pasir, peluang kerja sektor pertambangan juga sama sekali tidak terbuka untuk masyarakat. Bahkan menurut keterangan pemerintah desa, sejak beberapa tahun belakangan hingga bulan April 2014 tidak ada masyarakat Desa Rancapaku yang bekerja di sektor pertambangan.

Kondisi tersebut namun secara tidak langsung juga menunjukkan bahwa keberadaan perusahaan pertambangan tidak membuka peluang pekerjaan di desa secara signifikan. Bahkan fakta dilapangan menunjukkan semakin banyak masyarakat baik dari Desa Mekarjaya ataupun Desa Rancapaku yang bekerja sebagai buruh kasar, bahkan hingga harus merantau ke luar kota. Memang banyak masyarakat yang beranggapan pada saat ini pasir tidak lagi membawa "berkah" seperti yang mereka rasakan ketika sebelum masuknya industri pertambangan yang mulai menggunakan alat-alat berat.

Memang pada dasarnya, baik masyarakat Desa Rancapaku, maupun Desa Mekarjaya khususnya pada saat ini hampir sudah tidak ada yang menggantungkan secara mutlak penghidupan mereka pada sektor pertambangan. Hanya beberapa orang mungkin yang bertahan di sektor ini, itu pun biasanya hanya orang-orang yang memiliki relasi dan jabatan tertentu di perusahaan. Lebih lanjut, masyarakat juga mengatakan pada saat ini keuntungan hanya diperoleh oleh pihak-pihak yang memiliki otoritas dan kekuatan jaringan serta kekuasaan, dan bukan berada pada masyarakat sekitar ataupun buruh pertambangan. Hal ini seperti yang dapat dilihat pada Gambar 5. 


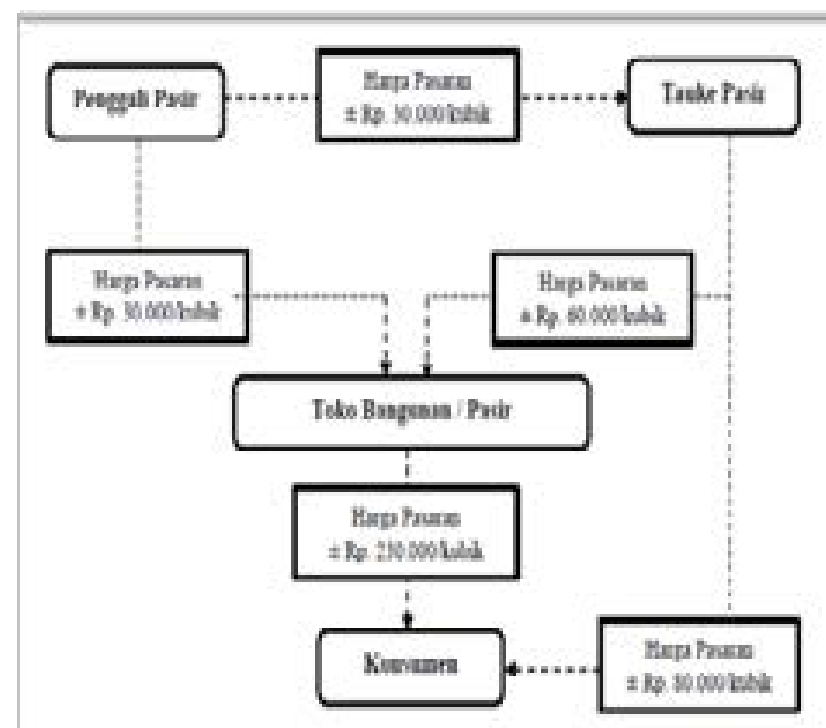

Gambar 5. Rantai Penjualan Pasir Galunggung

Berdasarkan Gambar 5, memang dapat terlihat jika penggali pasir yang langsung menjualnya ke toko bangunan atau tauke (pihak perusahaan atau kepala kerja suatu perusahaan pertambangan) hanya mendapat keuntungan yang tergolong rendah. Harga pasir yang berada di tangan pihak tauke setidaknya menjadi belipat dua kali lipat dari harga yang dijual oleh penggali tambang. Demikian halnya ketika tauke melakukan penjualan langsung ke konsumen, harga jual menjadi kembali bertambah menjadi sekitar Rp. 80.000 per-kubik. Harga yang ditawarkan tersebut setidaknya memiliki selisih harga sekitar Rp. 50.000 per-kubik dengan harga yang ditawarkan oleh penggali pasir.

Namun perbedaan yang paling terlihat adalah ketika pasir Galunggung telah dijual oleh pihak toko bangunan. Setidaknya terdapat selisih harga sebesar kurang lebih Rp. 200.000 per-kubik antara harga jual penggali pasir dan harga jual toko bangunan. Angka yang cukup jauh berbeda ini, telah mengindikasikan adanya ketidakadilan ekonomi yang terjadi antara pihak-pihak yang sama-sama memanfaatkan objek material pasir Galunggung.

Padahal secara logika, para pekerja dan penggali pasir tersebut merupakan pihak yang harus lebih banyak menguras waktu dan tenaga. Namun insentif dan keuntungan yang diperoleh oleh para pekerja seolah sangat tidak adil dan justru menguntungkan pihak pemodal saja. Konstruksi sistem kapitalisme yang dipraktikan oleh pihak swasta secara nyata hanya akan semakin memunculkan kesenjangan antara pihak pekerja dan pemodal. Pihak pekerja (masyarakat) yang mengidamkan kesejahteraan akan selalu terganjal oleh perbedaan cara pandang dan ideologi yang saling bertentangan.

Berdasarkan berbagai pernyataan di atas, dapat disimpulkan jika keberadaan perusahaan pertambangan telah memberikan dampak ekonomi yang nyata baik pada Desa Mekarjaya ataupun Desa Rancapaku. Namun kondisi yang dampak negatif lebih dirasakan oleh masyarakat yang berada di Desa Rancapaku, berbeda dengan masyarakat Desa Mekarjaya yang justru cenderung berada pada respons yang netral dan beberapa responden bahkan menyatakan keberadaan perusahaan tambang membawa manfaat yang positif.

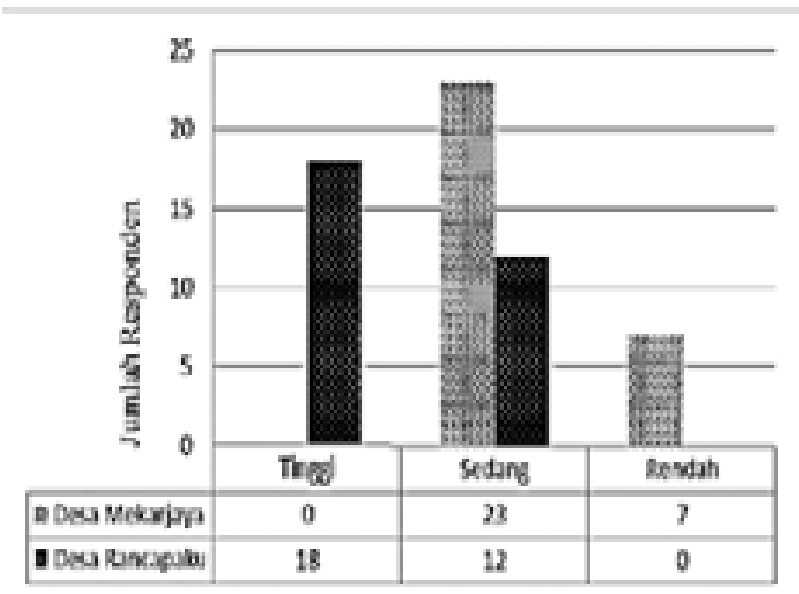

Dampak Eloovei Nitivitas Patenharga Pair

Gambar 6. Perbandingan persepsi responden terhadap dampak ekonomi pertambangan pasir

Keberadaan perusahaan pertambangan pasir pada akhirnya tidak mempengaruhi kondisi ekonomi ataupun pendapatan secara berarti. Hanya sedikit masyarakat Desa Mekarjaya yang bekerja di perusahaan tambang, dan hal tersebut nyatanya juga tidak mampu memberikan keadilan dan peningkatan ekonomi masyarakat. Namun dampak negatif lebih dirasakan oleh masyarakat Desa Rancapaku, dimana mereka sama sekali tidak memperoleh insentif atau manfaat keberdaan perusahaan pertambangan, namun bahkan harus merasakan dampak negatif dari perusahaan pertambangan yang terus berpengaruh terhadap penghidupan mereka. Seperti diantanya luapan air sungai yang diakibatkan pendangkalan, yang pada akhirnya merusak sawah masyarakat di Desa Rancapaku, dan kerap menciptakan gagal panen.

\section{SIMPULAN DAN SARAN}

\section{Simpulan}

1. Terdapat tiga aktor besar yang terlibat dalam kontestasi kepentingan atas pertambangan pasir di kawasan Gunung Galunggung, yakni masyarakat, pemerintah dan swasta. Masing-masing aktor tersebut memiliki ideologi dan cara pandang yang berbeda. Masyarakat yang menekankan pada kesejahteraan dan populisme, bertolak belakang dengan orientasi pihak swasta yang cenderung mementingkan profit. Tidak jarang hal ini juga pada akhirnya memunculkan protes atau gelombang pergerakan di lapisan masyarakat sipil yang menuntut adanya keadilan atas tidak berimbangnya keuntungan yang diperoleh antara masyarakat dan pihak swasta. Keberadaan perusahaan tambang yang seharusnya mampu mensejahterakan masyarakat, justru malah menciptakan kesenjangan yang baru.

Lemahnya law enforcement juga menyebabkan celah penyimpangan kebijakan dapat dengan mudah disusupi. Terbukti dengan aturan atau perizinan yang tidak melalui proses semestinya, mengindikasikan adanya deal politik 
yang terjadi antara oknum pemerintah dengan swasta. Padahal, permasalahan pertambangan di Gunung Galunggung merupakan permasalahan kompleks yang membutuhkan penyelesaian komperhensif stakeholders terkait.

2. Telah terjadi perubahan ekologi, sosial dan ekonomi baik di Desa Mekarjaya maupun Desa Rancapaku, namun secara esensial, dampak negatif justru lebih dirasakan oleh masyarakat Desa Rancapaku yang merupakan desa yang berada jauh dengan lokasi pertambangan. Secara garis besar, perubahan yang telah terjadi akibat aktivitas penambangan pasir adalah: (a) degradasi kualitas air dimana sebagian besar sumber air di tingkat desa telah tercemar oleh limbah penambangan pasir (b) lalu lalang truk pengangkut pasir yang menyebabkan udara dipenuhi debu dan jalan yang hancur yang pada akhirnya menghambat mobilitas masyarakat (c) bencana banjir dan longsor yang diakibatkan oleh penyusutan sungai dan konversi lahan untuk kepentingan penambangan (d) konflik baik laten maupun manifes yang bersifat horizontal dan juga vertikal (e) munculnya apatisme masyarakat terhadap kelestarian lingkungan (f) munculnya peluang usaha dan kerja baru baik yang secara langsung maupun tidak langsung diakibatkan oleh keberadaan penambangan pasir.

\section{Saran}

1. Perlu adanya tindakan penanggulangan limbah secara spesifik dan serius oleh pihak swasta dan pemerintah dengan memegang teguh asas transparansi dan pelibatan masyarakat secara mutlak, baik dari hulu hingga hilir. Terlebih mengingat aktivitas penambangan pasir di kawasan Gunung Galunggung telah dilakukan sejak lama, dimana sudah terdapat belasan atau bahkan puluhan perusahaan tambang yang keluar-masuk untuk melakukan pengerukan pasir di kawasan ini. Sehingga pemulihan kondisi lingkungan dan pemberhentian aktivitas pertambangan secara temporer mungkin dapat menjadi opsi yang harus dipertimbangkan secara khusus.

2. Kebijakan afirmatif yang pro-rakyat di tingkat daerah perlu diciptakan untuk mendukung sinergi yang saling menguntungkan antar stakeholders terkait.

Law enfocement juga perlu ditekankan untuk menciptakan regulasi yang sesuai amanat konstitusi dengan tendensi populisme yang sejati. Kebebasan pemerintah yang berlandaskan otonomi daerah seharusnya menjadikan pihak pemerintah mampu mengelola objek tambang pasir di kawasan Gunung Galunggung menjadi objek yang memiliki nilai jual dan posisi pasar yang strategis, dimana selain dapat memberikan peningkatan pendapatan asli daerah namun juga dapat memberi peningkatan pendapatan bagi masyarakat.

\section{DAFTAR PUSTAKA}

\section{Dharmawan} Mewujudkan

$\mathrm{AH}$.

2006. good ecological governance dalam pengelolaan sumberdaya alam. [Internet]. [diunduh 3 Februari 2014]. Dapat diunduh dari: Erwiantono. 2004. Hubungan antara karakteristik komunikasi dan sikap komunitas terhadap perusahaan (kasus pertambangan timah di Kabupaten Bangka Barat) [tesis]. Bogor [ID]: Institut Pertanian Bogor. 115 hal.
Keraf AS. 2010. Etika lingkungan hidup. Jakarta [ID]: Kompas. 408 hal. Lay C. 2007. Nilai strategis isu lingkungan dalam politik Indonesia. Jurnal Ilmu Sosial dan Ilmu Politik. [Internet]. [dikutip 11 Oktober 2013]. 11(2): 153-172. Dapat diunduh dari: http://jurnalsospol.fisipol.ugm.ac.id/ index.php/jsp/ article/download/51/42.

Samad F. 2013. Dampak pertambangan nikel terhadap sosial - ekonomi - ekologi masyarakat di Kecamatan Wasile Kabupaten Halmahera Timur. [tesis]. Bogor [ID]: Institut Pertanian Bogor. 84 hal.

Soemarwotto O. 1997. Ekologi, lingkungan hidup dan pembangunan. Jakarta [ID]: Djambotan. 381 hal

Suriansyah EA. 2009. Dampak pertambangan terhadap fungsi ekonomi lingkungan dan pendapatan masyarakat. [tesis]. Bogor [ID]: Institut Pertanian Bogor. 106 hal.

Tarmansyah US. 201129 Juni. Dampak negatif otonomi daerah dan peran dephan dalam pendayagunaan sumber daya nasional untuk kepentingan pertahanan negara. [Internet]. [diunduh 5 Februari 2014]. Badan Penelitian dan Pengembangan Kementrian Pertahanan RI. Utama: [tidak ada nomor halaman dan kolom]. Dapat diunduh dari: http://www.balitbang.kemhan.go.id/?q=content/da mpak-negatif-otonomi-daerah-dan-peran-dephandalam-pendayagunaan-sumber-daya-nasional-untu. Thoha M. 2004. Perilaku organisasi: Konsep dasar dan aplikasinya. Jakarta (ID): PT Raja Grafiindo 